\title{
Hubungan Persepsi Dengan Kualitas Hidup Pasien Hipertensi Lanjut Usia di RSUD Sultan Syarif Mohamad Alkadrie Pontianak
}

\author{
Correlation of Perception with Quality of Life in Elderly Hypertension Patients at Sultan Syarif Mohamad \\ Alkadrie Hospital Pontianak
}

\author{
Nabilla Putri Pratiwi ${ }^{1}$, Eka Kartika Untari ${ }^{2 *}$, Robiyanto ${ }^{2}$ \\ 1. Program Studi Farmasi, Fakultas Kedokteran Universitas Tanjungpura \\ 2. Departemen Farmakologi dan Klinik, Program Studi Farmasi, Fakultas Kedokteran Universitas Tanjungpura \\ Submitted: 02-05-2019 Revised: 22-02-2020 Accepted: 05-06-2020
}

Korespondensi : Eka Kartika Untari : Email : ekakartika@pharm.untan.ac.id

\begin{abstract}
ABSTRAK
Hipertensi sampai saat ini masih menjadi masalah kesehatan bagi kelompok lansia. Persepsi pasien lanjut usia (lansia) tentang penyakit hipertensi sering keliru sehingga membuat penyakit hipertensi pada lansia sering diabaikan dan berdampak pada kualitas hidupnya. Tujuan dari penelitian ini adalah untuk mengetahui persepsi pasien dan kualitas hidup pasien lansia yang mengalami hipertensi, serta hubungan antara persepsi pasien dengan kualitas hidup pasien lansia yang mengalami hipertensi di RSUD Sultan Syarif Mohamad Alkadrie Pontianak. Metode penelitian yang digunakan ialah observasional dengan rancangan survei analitik. Instrumen yang digunakan yaitu Brief IIIness Perception Questionnaire (B-IPQ) dan EuroQol five-dimension (EQ-5D-3L) versi Indonesia yang sudah valid dan reliabel. Subjek dalam penelitian ini yaitu pasien hipertensi rawat jalan di RSUD Sultan Syarif Mohamad Alkadrie Pontianak yang berumur > 60 tahun. Teknik sampling yang digunakan yaitu purposive sampling dengan 118 orang responden. Pengumpulan data diperoleh melalui instrumen B-IPQ untuk mengukur persepsi pasien, dan EQ-5D-3L untuk mengukur kualitas hidup pasien. Hubungan antara persepsi dengan kualitas hidup dianalisis menggunakan Fisher's Exact Test dengan taraf kepercayaan 95\% $(\alpha=0,05)$. Hasil penelitian didapatkan persentase responden yang memiliki persepsi positif sebesar 74,22 \%, dan kualitas hidup baik sebesar 76,56 \%. Hasil analisis statistik menunjukkan terdapat hubungan yang signifikan antara persepsi pasien dengan kualitas hidup pasien lanjut usia yang mengalami hipertensi di RSUD Sultan Syarif Mohammad Alkadrie dengan nilai $\mathrm{p}=0,000$.
\end{abstract}

Kata kunci: lansia; persepsi penyakit; kualitas hidup; hipertensi

\section{ABSTRACT}

Hypertension is still a health problem for the elderly group. The misperception about hypertension still occurs to the elderly. They often ignore hypertension and it impact their quality of life. The aim of this study is to obtain patient perceptions and the elderly's quality of life who are experiencing hypertension, also the relationship between patient perceptions and the elderly's quality of life who are experiencing hypertension at Sultan Syarif Mohamad Alkadrie Hospital Pontianak. This study was observational with analytival survey design. EQ-5D-3L (EuroQol five dimensions and B-IPQ (Brief Illness Perception Questionnaire) Indonesian version are instruments used which were valid and reliable. The subjects were hypertensive outpatient attending Sultan Syarif Mohamad Alkadrie Hospital Pontianak at aged $>60$ years. The sample size was 118 respondents which were obtained from purposive technique sampling. Data was collected through B-IPQ instruments to measure patient perceptions, and EQ-5D-3L to measure patients' quality of life. The relationship between perception and quality of life was analyzed using Fisher's Exact Test with a 95\% confidence level $(\alpha=0.05)$. The results showed the percentage of respondents who had a positive perception was $74.22 \%$, and good quality of life was $76.56 \%$. The results of statistical analysis show there is a significant relationship between patient perceptions and the quality of life of elderly patients who experience hypertension at Sultan Syarif Mohamad Alkadrie Hospital Pontianak with value of $p=0,000$.

Keywords: elderly; disease perception; quality of life; hypertension

\section{PENDAHULUAN}

Hipertensi sampai saat ini masih menjadi masalah kesehatan bagi kelompok lansia. Penelitian Pratiwi dan Tala menyebutkan, $74,8 \%$ pasien hipertensi berada di rentang usia 60-74 tahun dan $25,2 \%$ berada 
di rentang usia 54-60 tahun ${ }^{1}$. Hipertensi pada lansia sebagian besar merupakan hipertensi sistolik terisolasi (HST) yang ditandai dengan peningkatan sistolik yang menyebabkan besarnya kemungkinan timbulnya kejadian stroke dan infark miokard. Pengobatan hipertensi pada lansia biasanya menggunakan jenis terapi kombinasi ${ }^{2}$.

Persepsi terhadap penyakit ialah interpretasi yang dilakukan individu berkaitan dengan penyakit yang dideritanya dan dapat menjadi penuntun individu dalam memilih strategi pengendalian penyakit ${ }^{3}$. Persepsi pasien tentang penyakit dapat diukur dengan menggunakan suatu instrumen salah satunya yaitu Brief Ilness Perception Questionnaire (B-IPQ). Persepsi pasien lanjut usia tentang penyakit hipertensi sering salah seperti penyakit hipertensi tidak perlu penanganan serius, mudah sembuh, tidak perlu obat, dan dengan bertambah usia maka akan semakin tinggi batas normalnya. Anggapan seperti itulah yang akan membuat penyakit hipertensi pada lanjut usia sering diabaikan dan merasa tidak perlu serius dalam mengobati. Selain itu, tingkat kepatuhan yang rendah pada lansia juga akan mempengaruhi efektifitas pengobatan yang nantinya akan berdampak pada kualitas hidupnya ${ }^{4}$.

Kualitas hidup terkait kesehatan adalah penilaian status kesehatan yang dipersepsikan sendiri oleh pasien, penggambaran kualitas hidup dan kesejahteraan pasien bukan berdasarkan gejala klinis atau variabel patologis. Kualitas hidup merupakan perasaan puas seorang individu terhadap kehidupan secara menyeluruh dan menjalani kehidupannya dalam kondisi yang nyaman, serta jauh dari ancaman ${ }^{5}$. Kualitas hidup digunakan sebagai acuan dalam penilaian outcome pasien. Prinsip penilaian kualitas hidup ialah mengukur sejauh mana pasien dapat melaksanakan aktivitasnya sehari-hari secara normal walaupun terganggu oleh penyakit yang dideritanya ${ }^{6}$. Pengukuran kualitas hidup bisa menggunakan instrumen salah satunya dengan EQ-5D (EuroQol-five dimension) versi EQ-5D-3L. Instrumen ini merupakan instrumen yang paling banyak direkomendasikan dan lebih sederhana, akan tetapi mampu menggambarkan aspek kualitas hidup pasien secara komprehensif ${ }^{7}$. Selain itu, instrumen ini telah tersedia dalam versi bahasa Indonesia sehingga dapat digunakan untuk tujuan yang sama ${ }^{8}$.

Penelitian mengenai persepsi penyakit dan kualitas hidup pasien lansia dengan hipertensi juga diteliti oleh beberapa peneliti di Indonesia. Penelitian yang sedang berlangsung 30 tahun terakhir telah menunjukkan pentingnya representasi penyakit terhadap perilaku pasien. Meningkatkan atau mengubah persepsi pasien terhadap penyakit telah terbukti meningkatkan pemulihan setelah infark miokard (MI), dan kontrol diri pada diabetes dan AIDS9. Penilaian atau representasi mengenai penyakit secara kognitif pada pasien meliputi aspek identitas, konsekuensi, penyebab, lama penyakit, dan kesembuhan. Kelima aspek ini terdapat dalam instrumen BIPQ.

Persepsi terhadap suatu penyakit dapat mempengaruhi kualitas hidup pasien, jika persepsi yang baik diyakini akan meningkatkan motivasi, kepatuhan dalam pengobatan, serta perubahan gaya hidup yang lebih baik agar tercapainya peningkatan kualitas hidup ${ }^{10}$. Perbaikan kualitas hidup dapat menurunkan angka mortalitas dan morbiditas penyakit sehingga penilaian kualitas hidup dan persepsi pasien lanjut usia yang mengalami hipertensi perlu dilakukan sebagai acuan dalam monitoring dan evaluasi dalam manajemen terapi ${ }^{11}$.

\section{METODE}

Penelitian ini menggunakan metode observasional dengan rancangan survei analitik. Metode pengumpulan data secara potong lintang dengan menggunakan instrumen yang telah valid dan reliabel. Pengukuran persepsi menggunakan B-IPQ yang telah valid dan reliabel dengan nilai korelasi setiap butir pertanyaan lebih besar 
dari $r$ tabel $(0,3)$ dan nilai cronbach alpha sebesar $0,807>0,7^{12}$. Sedangkan pengukuran kualitas hidup menggunakan EQ-5D dengan nilai korelasi lebih besar dari $r$ tabel $(>0,7)$ dan cronbach alpha sebesar 0,718 >0,713.

Teknik samping yang digunakan adalah metode non probability sampling yaitu purposive sampling dengan memilih partisipan penelitian sesuai dengan kriteria inklusi dan tidak satupun yang memenuhi kriteria eksklusi. Kriteria inklusi pada penelitian ini antara lain pasien dengan riwayat penyakit hipertensi berusia $>60$ tahun, pasien rawat jalan, pasien yang dapat memahami instruksi B-IPQ dan EQ-5D versi Indonesia, dan pasien yang bersedia berpartisipasi dalam penelitian ini dengan menandatangani informed consent. Sedangkan kriteria eksklusi dalam penelitian ini yaitu pasien yang tidak mengisi instrumen B-IPQ dan EQ-5D versi Bahasa Indonesia dengan lengkap dan jelas.

Jumlah partisipan penelitian yang terlibat didapatkan melalui perhitungan minimal jumlah sampel dibawah ini:

$$
n=\frac{N \cdot z^{2} \cdot p \cdot q}{d^{2}(N-1)+z^{2} \cdot p \cdot q}
$$

Keterangan: $\mathrm{N}=$ jumlah populasi; $\mathrm{z}=1,96$ merupakan indeks untuk nilai kepercayaan 95 $\% ; \mathrm{p}=$ proporsi populasi, jika tidak diketahui maka $\mathrm{p}=0,5 ; \mathrm{q}=1-\mathrm{p} ; \mathrm{d}=$ kesalahan yang dapat ditolerir; $\mathrm{n}=$ jumlah sampel

$$
n=\frac{148(1,98)^{2} \cdot 0,5 \cdot 0,5}{0,5^{2}(147)+(1,96)^{2} \cdot 0,5 \cdot 0,5}
$$

$\mathrm{n}=107$ sampel dilebihkan $10 \%$ jadi dibutuhkan 118 sampel

Data didapatkan melalui pengisian instrumen B-IPQ dan EQ-5D yang disertai wawancara dan dilakukan setelah pasien mendapatkan penjelasan singkat mengenai maksud dan tujuan penelitian, menyetujui menjadi partisipan dan mengisi informed consent. Pengisian kuesioner dapat dilakukan oleh pasien atau bila diperlukan dapat dibantu oleh keluarga maupun peneliti. Penilaian persepsi dengan instrumen B-IPQ ditentukan dengan menjumlahkan total skor setiap butir pertanyaan yaitu 0-80. Persepsi dikategorikan menjadi data ordinal yaitu persepsi positif $\leq$ median (40); dan negatif $>$ median (40) ${ }^{14}$. Penilaian kualitas hidup melalui EQ-5D-3L melalui nilai indeks pada tiap dimensi yaitu: 1=subjek tidak memiliki masalah; 2=subjek memiliki beberapa masalah; dan $3=$ subjek sangat memiliki masalah. Nilai indeks ini isi pada kolom isian EQ-5D-3L index calculator, maka secara otomatis akan keluar skor kualitas hidup. Jika skor total $<0,5=$ kualitas hidup buruk; sedangkan $\geq 0,5=$ kualitas hidup baik $^{15}$. Hasil pengumpulan data kemudian diubah ke dalam bentuk tabel dan diolah menggunakan analisis statistik. Analisis univariat dianalisis secara deskriptif dalam bentuk tabel berupa frekuensi dan presentase. Analisis bivariat dilakukan menggunakan program IBM SPSS Statistic 22 menggunakan Fisher's Exact Test. Nilai p-value $(\mathrm{p}<0,05)$ menunjukkan terdapat hubungan. Uji ini dipilih untuk sel pada tabel yang nilainya $<5$.

\section{HASIL DAN PEMBAHASAN}

Penelitian ini telah mendapatkan surat keterangan lolos kaji etik dari Divisi Kaji Etik Fakultas Kedokteran Universitas Tanjungpura dengan nomor surat, NO: 194/UN22.9/DL/2019. Hasil penelitian mengenai hubungan antara persepsi pasien dengan kualitas hidup pasien lansia yang mengalami hipertensi di RSUD Sultan Syarif Mohamad Alkadrie Pontianak adalah sebagai berikut.

\section{Karakteristik Pasien}

Secara detail karakteristik pasien dapat dilihat pada tabel I. Penyakit hipertensi pada lansia banyak dialami perempuan dengan jumlah pasien 60 orang $(50,85 \%)$ dibandingkan dengan laki-laki yang berjumlah 58 orang (49,15\%). Hasil ini sesuai dengan Profil Kesehatan Kalbar 2017 yang mengatakan berdasarkan jenis kelamin prevalensi hipertensi lebih tinggi terjadi pada perempuan dibanding laki-laki ${ }^{16}$. Menurut Wahyuningsih, wanita ketika sudah memasuki usia 50 tahun kadar hormone 
Tabel I Deskripsi Karakteristik Pasien (N=118)

\begin{tabular}{llcc}
\hline Karakteristik & Kategori & Frekuensi & Persentase (\%) \\
\hline Jenis Kelamin & Pria & 58 & 49,15 \\
& Wanita & 60 & 50,85 \\
Usia (Tahun) & $61-70$ & 107 & 90,68 \\
Penyakit Penyerta & $71-80$ & 11 & 9,32 \\
& Ada & 87 & 73,72 \\
Diagnosis Hipertensi & Tidak Ada & 31 & 26,27 \\
& HST & 76 & 64,41 \\
& (Hipertensi Sistolik & & \\
\multirow{2}{*}{ Jenis Terapi Anti Hipertensi } & Terisolasi) & & \\
& Non HST & 42 & 35,59 \\
& Tunggal & 36 & 30,51 \\
& Kombinasi & 82 & 69,49 \\
\hline
\end{tabular}

estrogen yang dijadikan pelindung pembuluh darah semakin berkurang sehingga hipertensi pada usia lanjut lebih sering terjadi pada wanita dibanding pria ${ }^{17}$.

Usia yang paling banyak menderita hipertensi ialah usia 61-70 tahun dengan persentase $90,68 \%$. Hal ini didukung oleh penelitian yang dilakukan oleh Rahajeng bahwa, semakin bertambahnya usia, resiko terjadinya hipertensi juga semakin besar. Setelah usia 45 tahun, dinding arteri akan mengalami penebalan karena adanya penumpukan zat kolagen pada lapisan otot, sehingga pembuluh darah akan berangsurangsur kaku dan menyempit. Tekanan darah sistolik dan tekanan darah diastolik meningkat karena kelenturan pembuluh darah besar yang berkurang seiring dengan penambahan usia ${ }^{18}$.

Komorbid atau penyakit penyerta adalah salah satu faktor yang berpengaruh terhadap peningkatan resiko penyakit hipertensi. Berdasarkan penelitian yang telah dilakukan, pasien hipertensi lebih banyak yang dengan penyakit penyerta yaitu sebanyak 87 orang $(73,72 \%)$. Semakin bertambahnya usia, fungsi fisiologis dari berbagai organ tubuh dan daya tahan tubuh semakin menurun, sehingga lansia lebih rentan mengalami penyakit menular maupun tidak menular ${ }^{19}$. Penyakit penyerta yang sering dialami yaitu diabetes melitus, gagal ginjal, hiperkolesterol, Penyakit Paru
Obstruktif Kronik (PPOK), rheumatoid arthritis, dan dyspepsia. Namun, penyakit penyerta yang paling banyak diderita oleh pasien dalam penelitian ini ialah diabetes melitus (DM). Hal ini didukung oleh penelitian yang dilakukan oleh Mutmainah, dimana terdapat sebanyak $80 \%$ penderita hipertensi yang mengalami gangguan atau peningkatan kadar gula darah.

Pasien dengan diagnosis hipertensi sistolik terisolasi (HST) lebih dominan yaitu sebanyak 76 orang $(64,41 \%)$. Hal ini disebabkan karena pasien penderita hipertensi sistolik terisolasi sebagian besar berusia $>60$ tahun. Menurut Jannah dkk, semakin bertambahnya usia dinding arteri akan mengalami penebalan oleh karena adanya penumpukan zat kolagen pada lapisan otot, sehingga pembuluh darah akan berangsurangsur kaku dan menyempit. Peningkatan tekanan darah terjadi karena berkurangnya kelenturan pembuluh darah besar dengan seiring bertambahnya usia ${ }^{20}$.

Jenis terapi yang digunakan terdiri dari monoterapi dan kombinasi. Pasien yang mendapatkan terapi kombinasi lebih banyak yaitu sebanyak 82 orang dibandingkan pasien yang mendapatkan terapi tunggal atau monoterapi yaitu sebanyak 36 orang. Hal ini didukung oleh penelitian yang dilakukan Fitrianto dkk, yang mengatakan bahwa penggunaan terapi kombinasi diberikan bagi pasien hipertensi yang disertai dengan 
Hubungan Persepsi Dengan Kualitas Hidup Pasien Hipertensi

Tabel II Distribusi Kualitas Hidup dan Persepsi Penyakit (N=118)

\begin{tabular}{llcc}
\hline & & Frekuensi & Persentase (\%) \\
\hline Persepsi Pasien & Positif $(<$ Median 40) & 94 & 79,66 \\
& Negatif $(>$ Median 40$)$ & 24 & 20,34 \\
Kualitas Hidup & Baik $(\geq 0,5)$ & 97 & 82,20 \\
& Buruk $(<0,5)$ & 21 & 17,80 \\
\hline
\end{tabular}

Tabel III Skor EQ-5D-3L dan Persepsi Pasien Lansia berdasarkan Usia dan Penyakit Penyerta $(\mathrm{N}=118)$

\begin{tabular}{llccc}
\hline & & \multirow{2}{*}{ Skor EQ-5D-3L } & \multicolumn{2}{c}{ Persepsi } \\
\cline { 4 - 5 } & & 0.74 & Negatif & Positif \\
\hline \multirow{2}{*}{ Usia (Tahun) } & $61-70$ & 0.66 & 20 & 85 \\
\multirow{2}{*}{ Penyakit Penyerta } & $71-80$ & 0.68 & 22 & 9 \\
& Ada & 0.86 & 2 & 65 \\
& Tidak Ada & & 29 \\
\hline
\end{tabular}

penyakit penyerta seperti diabetes melitus, stroke, infark miokard, dan gagal jantung ${ }^{21}$. Terapi kombinasi juga diberikan untuk pasien yang sulit mencapai sasaran tekanan darah. Golongan obat antihipertensi yang paling sering digunakan untuk terapi kombinasi ialah Calcium Channel Blocker (CCB) dan Angiotensin Renin Blocker (ARB). Penggunaan kombinasi ARB dan CCB memiliki manfaat dalam mengurangi tingkat morbiditas dan mortalitas pada penyakit kardiovaskular, infark miokard, dan stroke ${ }^{22}$.

\section{Gambaran Persepsi Penyakit}

Penilaian tentang persepsi penyakit hipertensi didasarkan pada skor jawaban item 1-8 pada kuesioner B-IPQ (Brief Illness Perception Questionnaire). Menurut Lochting et al (2013), skor yang lebih tinggi menunjukkan bahwa penyakit tersebut dianggap ancaman dengan rentang nilai total 0-80. Penyakit hipertensi dianggap ancaman atau dinilai persepsi negatif apabila skor total berada diatas nilai median yaitu $40^{14}$. Hasil penelitian didapatkan skor total ialah 32.13 yang menunjukkan bahwa persepsi pasien tentang penyakit hipertensi di RSUD Sultan Syarif Mohamad Alkadrie Pontianak cenderung positif. Pasien hipertensi lansia yang memiliki persepsi positif sebanyak 94 orang $(79,66 \%)$ sedangkan persepsi negatif sebanyak 24 orang $(20,34 \%)$. Ginandjar dkk mengatakan bahwa semakin pasien berpersepsi yang serius dan parah terhadap suatu penyakit yang diderita maka semakin besar pula untuk mencari tindakan pencegahannya. Pasien akan mengubah perilaku mereka berdasarkan ancaman keparahan suatu penyakit. Sehingga akan menimbulkan persepsi yang positif terhadap penyakitnya ${ }^{23}$. Pada tabel III sebagian besar persepsi positif terhadap penyakit hipertensi baik pada kelompok usia yang lebih lanjut dan keberadaan penyakit penyerta. Variabel yang diduga berpengaruh pada lansia dalam mengendalikan tekanan darahnya adalah persepsi mengenai manfaat dan ancaman akibat melakukan suatu tindakan. Seorang lanjut usia mempunyai keyakinan bahwa penyakit hipertensi yang dideritanya tersebut akan bertambah parah atau sembuh dan merasakan penyakit tersebut merupakan suatu masalah yang harus segera diatasi $^{3}$. Sehingga lansia akan berupaya meningkatkan kualitas hidup melalui persepsi positif yang dibangunnya. Beberapa pasien dengan penyakit penyerta terdistribusi memiliki persepsi yang negatif, hal ini dikarenakan pasien lansia memiliki ancaman kerentanan diri terhadap penyakit. Ancaman suatu penyakit dipersepsikan secara berbeda 
oleh setiap individu. Ada yang takut terhadap penyakit itu, sehingga mereka akan bertujuan untuk membentuk perilaku hidup sehat. Pemahaman akan penyakit hipertensi

Tabel IV Hubungan Persepsi Pasien Tentang Penyakit Hipertensi dengan Kualitas Hidup ( $\mathbf{N = 1 1 8 )}$

\begin{tabular}{|c|c|c|c|c|c|}
\hline \multirow{2}{*}{ Persepsi Pasien } & \multicolumn{2}{|c|}{ Kualitas Hidup } & \multirow{2}{*}{ Total } & \multicolumn{2}{|c|}{ fisher } \\
\hline & Baik & Buruk & & $\mathbf{P}$ & r hitung \\
\hline Positif & 92 & 2 & 94 & & \\
\hline Negatif & 5 & 19 & 24 & 0,000 & 0,811 \\
\hline Total & 97 & 21 & 118 & & \\
\hline
\end{tabular}

Keterangan: $\mathrm{r}$ tabel $=0,236$

melakukan praktik pengendalian penyakit, tapi ada juga yang menganggap penyakit itu tidak begitu parah ${ }^{3}$.

Penilaian mengenai kualitas hidup pasien hipertensi lansia ini didasarkan pada skor kuesioner EQ-5D-3L.). Nilai indeks tersebut didapat dari skor EQ-5D-3L yang telah dikonversi ke nilai indeks utility EQ-5D3L dengan menggunakan EQ-5D-3L index calculator. Kualitas hidup yang dimiliki 97 orang $(82,20 \%)$ pasien hipertensi pada lanjut usia dengan menggunakan kuesioner EQ-5D3L ialah baik, sedangkan kualitas hidup yang buruk sebesar 21 orang $(17,80 \%)$. Hasil penelitian ini sejalan dengan penelitian yang dilakukan oleh Ambarasan dengan target populasi yaitu usia diatas 60 tahun. Penelitian tersebut mendapatkan hasil bahwa kualitas hidup lansia dengan hipertensi secara umum baik ${ }^{24}$. Tabel II menunjukkan subjek penelitian cenderung memiliki nilai EQ-5D-3L yang mendekati indeks sebesar 1,00, hal ini sejalan bahwa sebagian besar pasien memiliki kualitas hidup yang baik dari sisi ada atau tidaknya penyakit penyerta dan pertambahan usia. Kualitas hidup dianggap baik jika 3 atau lebih dari 3 dimensi tidak ada masalah. Hal ini sejalan dengan penelitian yang dilakukan oleh Fithria, dimana sebagian besar subjek memiliki tingkat kualitas hidup yang baik ${ }^{25}$. Semakin bertambahnya usia, usaha membentuk perilaku hidup sehat dan pemahaman penyakit hipertensi semakin kuat. Ketika seorang lansia mengidap penyakit kronis maka lansia juga akan membentuk perilaku self management yang memberikan motivasi pada lansia untuk melakukan perilaku hidup sehat demi kesehatannya, sehingga kualitas hidupnya mengarah pada kualitas baik ${ }^{26}$.

\section{Hubungan antara Persepsi Pasien tentang Penyakit dengan Kualitas Hidup Pasien Lansia}

Berdasarkan hasil uji statistik fisher pada tabel IV didapatkan nilai $p$-value sebesar 0,00 atau $<0,05$, yang berarti terdapat hubungan yang signifikan antara variabel persepsi pasien dengan variabel kualitas hidup. Nilai $r$ hitung pada penelitian ini yaitu 0,811 atau nilai $r$ hitung $(0,811)>0,236$ (nilai $r$ tabel), maka dapat disimpulkan bahwa terdapat kecenderungan hubungan antara variabel persepsi pasien dengan variabel kualitas hidup. Nilai $r$ hitung dalam analisis ini bernilai positif maka itu artinya hubungan antara kedua variabel tersebut bersifat positif, dapat dikatakan bahwa semakin positif persepsi pasien maka semakin baik juga kualitas hidupnya ${ }^{10}$. Kontrol persepsi yang baik dapat mempengaruhi kualitas mental, morbiditas dan mortalitas ${ }^{10}$. Menurut Benyamini, ada hubungan antara persepsi pasien tentang penyakit dengan kualitas hidup lanjut usia. Pasien yang beranggapan kondisinya baik-baik saja cenderung mempunyai kualitas hidup yang baik, sehingga dimensi dari B-IPQ akan cenderung lebih positif ${ }^{27}$. Keterbatasan dalam penelitian ini adalah penilaian persepsi dan kualitas hidup tidak dilakukan hanya pada pasien hipertensi tanpa komorbid atau penyakit penyerta karena pasien lansia dengan tanpa 
komorbid sulit ditemukan karena hampir seluruh pasien lansia mengalami multipatologis. Selain itu kualitas hidup yang terukur adalah berdasarkan pandangan dari sudut pasien dan tidak dikaitkan dengan luaran pengobatan.

\section{KESIMPULAN}

Hasil analisis univariat menunjukkan bahwa pasien hipertensi lansia di RSUD Sultan Syarif Mohamad Alkadrie Pontianak cenderung memiliki persepsi positif dan kualitas hidup yang baik. Pada analisis bivariat dengan uji fisher menunjukkan terdapat hubungan antara persepsi pasien dengan kualitas hidup pasien lansia yang mengalami hipertensi dengan nilai $p$-value $=0,000$ pada taraf kepercayaan $95 \%$.

\section{DAFTAR PUSTAKA}

1. Pratiwi VR, Tala ZZ. Gambaran Status Gizi Pasien Hipertensi Lansia di RSUP H. Adam Malik Medan The Nutritional Status of Elderly Hypertensive Patient in RSUP H . Adam Malik. FK USU. 2013;1(1):1-5.

2. Konita S, Azmi S. Pola Tekanan Darah Pada Lansia di Posyandu Lansia Kelurahan Padang Pasir Padang Januari 2014. Kesehatan Andalas. 2014;4(1):269273.

3. Soesanto E, Istiarti T, Pietojo H. Praktik Lansia Hipertensi dalam Mengendalikan Kesehatan Diri di Wilayah Puskesmas Mranggen Demak. Promosi Kesehatan Indonesia. 2010;5(2):127-129.

4. A K. Analisis Faktor-faktor yang Mempengaruhi Kepatuhan Penderita Hipertensi Dalam Perawatan Hipertensi di Wilayah Kerja Puskesmas Cibeureum Kota Tasikmalaya. Kesehatan Bakti Tunas Husada. 2016;16(1):147-150.

5. Karimi M, Brazier J. Health, HealthRelated Quality of Life, and Quality of Life: What is the Difference? PharmacoEconomics. 2016;34(7):645649. doi:10.1007/s40273-016-0389-9.
6. Afiyanti Y. Analisis konsep kualitas hidup. Keperawatan Indonesia. 2010;13(2):83-84.

7. Horowitz E, Abadi-korek I, Shani M, Shemer J. EQ- $5 \mathrm{D}$ as a Generic Measure of Health-Related Quality of Life in Israel: Reliability, Validity and Responsiveness. Isr Med Assos J. 2010;12(1):715-720.

8. Dyah B, Perwitasari A. Perbandingan kualitas hidup pasien hipertensi menggunakan kuesioner eq- 5d dan sf6d di RS X Yogyakarta. Farmasains. 2017;2(6):253-258.

9. Broadbent E, Petrie KJ, Main J, Weinman J. The Brief Illness Perception Questionnaire. J Psychosom Research. 2006;60(1):631-637.

doi:10.1016/j.jpsychores.2005.10.020

10. Timmers L, Thong M, Dekker FW, et al. Illness perceptions in dialysis patients and their association with quality of life. Psychology \&amp; Health. 2008;23(6):679-690. doi:10.1080/14768320701246535.

11. Anbarasan SS. Gambaran Kualitas Hidup Lansia Dengan Hipertensi Di Wilayah Kerja Puskesmas Rendang Pada Periode 27 Februari Sampai 14 Maret 2015. Intisari Sains Medis. 2015;4(1):113. doi:10.15562/ism.v4i1.57.

12. Robiyanto, Prayuda AO dan NE. Uji Validitas Instrumen B-IPQ Versi Indonesia Pada Pasien Hipertensi di RSUD Sultan Syarif Mohamad Alkadrie Pontianak. Soc Clinic Pharmacy Indonesia Journal. 2016;1(1):48-49.

13. Sari A, Lestari NY dan P DA. Validasi ST European Quality of Life-5 Dimensions (EQ-5D) versi Indonesia Pada Pasien Hipertensi di Puskesmas Kotagede II Yogyakarta. Pharmaciana. 2015;5(2):131-138.

14. Løchting I, Am G, Storheim K, El W, Grotle M. Journal of Pain \& Relief Evaluation of the Brief Illness Perception Questionnaire in Sub-Acute and Chronic Low Back Pain Patients: Data Quality, Reliability and Validity. J 
Nabilla Putri Pratiwi, et al

Pain Relli. 2013;2(3):1-6. doi:10.4172/2167-0846.1000122

15. Rowen D, Brazier J, Roberts J. Mapping SF-36 onto the EQ-5D index: how reliable is the relationship? Biomed Central. 2009;7(27):1-11. doi:10.1186/1477-7525-7-27

16. Dinas Kesehatan Provinsi Kalimantan Barat. Profil Kesehatan Kalimantan Barat Tahun 2017. https://www.kemkes.go.id/resources/d ownload/profil/PROFIL_KES_PROVIN SI_2017/20_Kalbar_2017.pdf. Diakses 17 Januari 2019.

17. Astuti E W. Faktor Yang Mempengaruhi Hipertensi pada Usia Lanjut. Ners dan Kebidanan Indonesia. 2013;1(3):71-75.

18. Rahajeng E, Tuminah S. Prevalensi Hipertensi dan Determinannya di Indonesia. Majalah Kedokteran Indonesia. 2009;59(12):580-587.

19. Anorital. Morbiditas dan Multi Morbiditas Pada Kelompok Lanjut Usia di Indonesia. Jurnal Biotek Medisiana Indonesia. 2015;4(2):77-88.

20. Jannah M, Nurhasanah, Azmi NM SR. Analisis Faktor Penyebab Kejadian Hipertensi di Wilayah Kerja Puskesmas Mangasa Kecamatan Tamalate Makassar. PENA. 2017;3(1):409-417.
21. Fitrianto H, Azmi S, Kadri $H$. Penggunaan Obat Antihipertensi pada Pasien Hipertensi Esensial di Poliklinik Ginjal Hipertensi RSUP DR. M. Djamil. Kesehatan Andalas. 2014;3(1):45-48.

22. Armstrong C. JNC8 guidelines for the management of hypertension in adults. American family physician, 90(7), 503504.

23. Ginandjar P, Martini N. Faktor-faktor yang Berhubungan dengan Kepatuhan Pengobatan Masal di Kelurahan Non Endemis Filariasis Kota Pekalongan. Kesehatan Masyarakat. 2017;5(4):455-466.

24. SS A. Gambaran Kualitas Hidup Lansia Dengan Hipertensi di Wilayah Kerja Puskesmas Rendang Pada Periode 27 Februari Sampai 14 Maret 2015. Kedokteran. 2015;4(1):113-124.

25. Fithria. Kualitas Hidup Penderita Hipertensi di Desa Lamceu Kecamatan Kuta Baro Kabupaten Aceh Besar. Idea Nurse Journal. 2011;3(1):62-69.

26. Dewi S. Spiritualitas dan Persepsi Kesehatan Lansia dengan Hipertensi di Wilayah Kerja Puskesmas Mayang Jember. Indones Journal Health Scient. 2016;6(2):228-237.

27. Benyamini, Y. Goner-Shilo,D. Lazarov A. Illness Perception and Quality of Life in Patients with Contact Dermatitis. Contact Dermatitis. 2012;67(4):193-199 